\title{
Comparison of Service Quality and Stakeholder Perception on Bus Services for Urban Transportation in Klang Valley
}

Muhammad Fadhlullah Abu Bakar, Shuhairy Norhisham, Chow Ming Fai, Nur Lyana Baharin

To Link this Article: http://dx.doi.org/10.6007/IJARBSS/v11-i2/9210

DOI:10.6007/IJARBSS/v11-i2/9210

Received: 19 December 2020, Revised: 23 January 2021, Accepted: 16 February 2021

Published Online: 27 February 2021

In-Text Citation: (Bakar et al., 2021)

To Cite this Article: Bakar, M. F. A., Norhisham, S., Fai, C. M., \& Baharin, N. L. (2021). Comparison of Service Quality and Stakeholder Perception on Bus Services for Urban Transportation in Klang Valley. International Journal of Academic Research in Business and Social Sciences, 11(2), 1352-1362.

\section{Copyright: @ 2021 The Author(s)}

Published by Human Resource Management Academic Research Society (www.hrmars.com)

This article is published under the Creative Commons Attribution (CC BY 4.0) license. Anyone may reproduce, distribute, translate and create derivative works of this article (for both commercial and non-commercial purposes), subject to full attribution to the original publication and authors. The full terms of this license may be seen at: $\underline{\text { http://creativecommons.org/licences/by/4.0/legalcode }}$

Vol. 11, No. 2, 2021, Pg. 1352 - 1362

Full Terms \& Conditions of access and use can be found at http://hrmars.com/index.php/pages/detail/publication-ethics 


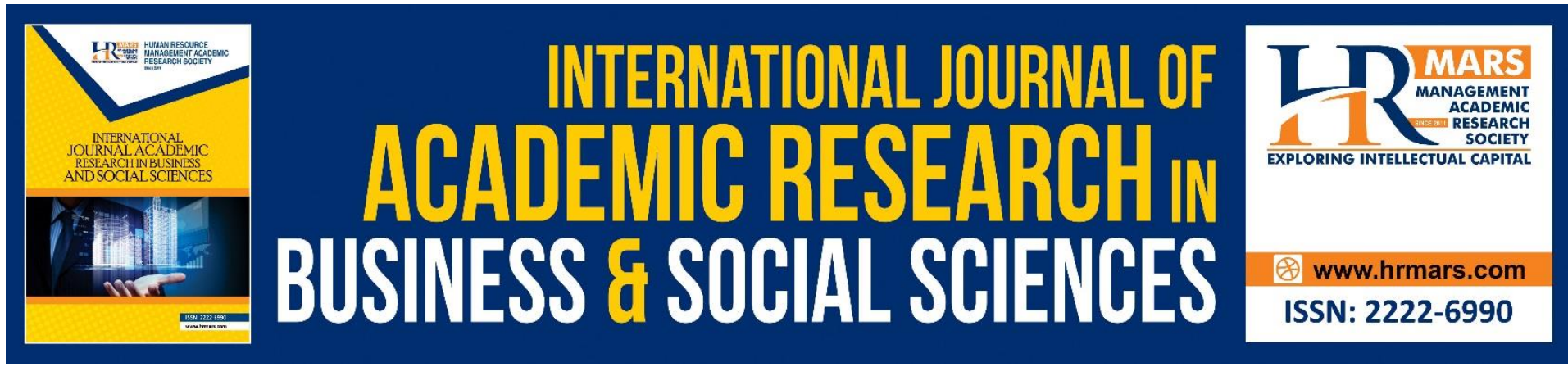

\title{
Comparison of Service Quality and Stakeholder Perception on Bus Services for Urban Transportation in Klang Valley
}

\author{
Muhammad Fadhlullah Abu Bakar ${ }^{1}$, Shuhairy Norhisham ${ }^{1,2}$, \\ Chow Ming Fai ${ }^{1,2}$, Nur Lyana Baharin ${ }^{3}$ \\ ${ }^{1}$ College of Engineering, Universiti Tenaga Nasional, 43000 Kajang, Selangor, Malaysia. \\ ${ }^{2}$ Institute of Energy Infrastructures (IEI), Universiti Tenaga Nasional, 43000 Kajang, Selangor, \\ Malaysia, ${ }^{3}$ College of Business Management \& Accounting, Universiti Tenaga Nasional, \\ 43000 Kajang, Selangor, Malaysia.
}

\begin{abstract}
Malaysia is one of the fastest grown countries in Asian Region. Rapid development in urban area has caused traffic problem which same as developed countries around the world. Kuala Lumpur also known as Klang Valley facing traffic congestions daily. In December 2015, Land Public Transport Commission as public transport authorities has launched The Klang Valley Network Revamp to solved public transport issues in Klang Valley. Unfortunately, there are several news have reported regarding poor service quality of bus services in Klang Valley. Therefore, these studies is to investigate the comparison between service quality and stakeholder perceptions in regarding bus services in Klang Valley. Service quality has been determined based on the service quality of bus services provided by operator. Stakeholder perceptions based on qualitative analysis conducted towards bus passenger or user in specific area. The results shows that Puchong and Petaling Jaya they have the same level of comparison of quality of service and stakeholder' view which is C. As in Klang, quality of service bus services that been evaluated as D but stakeholder's view has classified as $C$. Based on result, it can justified West Klang Valley has a good bus services and yet there are several issues could be addressed in future such as the certain driver performance could affect the quality service of bus and there are new development area should be reach by bus services.

Keywords: Public Transportations, Urban Transportation, Bus Services, Quality of Service, Stakeholder Perception.
\end{abstract}

\section{Introduction}

Traffic congestion is one major issued have been address by developing countries these day. Increasing of population would reflect the public transport demand and related issue (Aziz \& Mohamad, 2013). Public transportation is one of the alternatives to overcome these issues. In 2010, approximately more than 1.25 million daily trips in Klang Valley represent almost $25 \%$ of road users have used the public transport as a main transportation daily (Calvo, 2018; Margaret, 2018). Public transport should provide efficient and good service mobility to consumer or users and give significant impact to city system. Therefore, it is necessary to 
measure the service quality as a method to measure quality of public transport especially on bus services (Adebola et al., 2014) as well as to reduce the carbon footprint (Yang et al., 2010; Chuen et al., 2014). RapidKL is the major bus company that operates in urban areas of Klang Valley. It is a serviced brand operated by Prasarana Malaysia. Land Public Transport Commission (SPAD) in December 2015 has established The Klang Valley Network Revamp to manage public transportation in Klang Valley (Amiril, 2014). SPAD has received feedback form users recently regarding the quality of bus service in Klang Valley. Recently, the demand by bus passenger decrease due to the high competition between other alternative such as personal vehicle, e-haling and etc (Ibrahim et al., 2013). Service quality should be focused and addressed in order overcome bus service issues (Eboli \& Mazzulla, 2008).

Fundamentally, using public transport could reduce transport congestion, save travelling money and preserve environment. Increasing of people would reflect the public transport demand simultaneously (Haron et al., 2010). Trustworthiness of bus services also could be one of the issues for both operator and user because it would affect user experience and service quality perceptions (Saberi et al., 2013). Trustworthiness of service transit was an important issue for passenger transit and transit operator. Reducing the time waiting recently would provide the goof capacity and effectiveness and reduce excessive load. By reducing time waiting would increase trustworthiness and increasing efficiency of operation cost and low capital required (Vien et al., 2010). Quality of service is based on destination option and the demand itself (Attrad, 2013). Recently, there are a lot of improvement have been made in order to determine quality performance of public transport such as monitoring, controlling and management system by authority and operator (Saberi et al., 2013).

Quality of service provided by operator could be measured by performance of each bus (Eboli \& Mazzulla, 2018; Juan et al., 2014). The consistency of the service quality should be consistance form time to time (Saberi et al., 2013). Public transport should be an important element of mobility in city (Rahmat, 2015). Service quality of buses would be measured based on the speed and handling management of buses (Lin \& Wong, 2014). There were few issue have been rise such as lack of service information, inappropriate bus schedule and expensive ticket could be factor why people would not choose buses as main transportation (Soh et al., 2014; Bekhet \& Ivy, 2014). Lack of service quality provided by operator will caused unpleasant and unsafe for passenger and users. There were several parameters would affect the service such as low coordination of public transport by operators, limited passenger from sub urban, traffic congestion in town especially during peak hour and air and sound pollution (Enso, 2004); Ona et al., 2015). A lot of bus terminal and bus stop should be rectified for convenient of passenger, increase the frequency of bus service, improve the integration model for safety purposes and reduce total of transit before reach the final destination (Ensor, 2004; Mazzulla \& Eboli, 2006).

Customer's perception could be defined as review of customer based service performance transit (Eboli \& Mazzulla, 2012). Quality of service is the understanding on customer's demands that will affect the customer's perception on the service given. Therefore, good service quality would produce good customer perception on the service given (Azadi et al., 2015). Service quality of bus service is referred based on Manual of Transit Capacity and Quality Service Manual (TCQSM, 2013). It state that quality of service would be considered as passenger perception regarding the whole quality of transit service (Yaakub \& Napiah, 2011a). Level of service quality has been important aspect that should be addressed in order to produce good level of service (Calvo et al., 2018). Service process was divided by two part which was operation part (internal side) and customers (internal side) for quality and 
satisfaction perspective (Fonseca et al, 2010; Ahmad et al., 2014). Satisfaction was referred as customers reviews regarding service provided and customers reviews would represent customers needed from company performance (Eboli et al., 2018). Therefore, these studies were aimed to determine the comparison of service quality and stakeholder perception on the bus service for urban transportation in Klang Valley.

\section{Methodology}

These studies were covered on the steps described the comparison of service quality and stakeholder perception on bus service for urban transportation in Klang Valley. West Klang Valley which including Puchong, Subang Jaya, Klang, Shah Alam and Petaling Jaya have been selected as a studies area as these area consider major cities in Klang Valley. These studies were conducted in January 2018 and Figure 1 shows the areas covered in these studies.

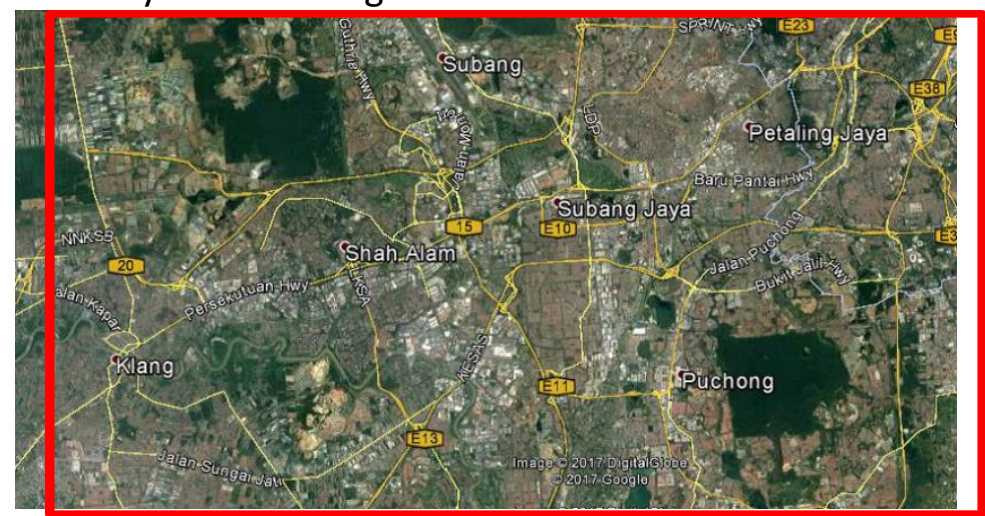

Figure 1: The areas covered in these studies.

Service quality data have been taken at selected route in these areas. Most of the route operated by RapidKL owned by Prasarana Berhad. For a RapidKL Bus, the total capacity is 65 passenger consists of 25 seated and 40 standing passenger. Three routes have been selected for each areas in the west of Klang Valley. The necessary data have been taken for each route were Shah Alam (Route T757, T758 and SA01), Petaling Jaya (Route PJ02, PJ03 and PJ04), Subang Jaya (Route T776, T777 and T778), Klang (Route KLG1, KLG2 and 704), and Puchong (Route T600, T604 and T605). The data collection was done in different time frames identified as below:

- $\quad$ Peak Hours in the Morning (7am-9am)

- Non-Peak Hours of the Day (11am-2pm)

- $\quad$ Peak Hours in the Evening (4pm-7pm)

- $\quad$ Non-Peak Hours of the Night (8pm-10pm)

The data have been collected for both weekdays and weekends. The total journeys for the data collection were four journeys for weekdays and four journeys for weekends, for each respective route in one area only. To sum up, the total journey for one area was 24 journeys, while the total journeys for the total five different areas was 120 journeys altogether. The conditions inside the buses are shown in Figure 1. Transit Capacity and Quality of Service Manual (TRCPM) has been referred as a guidelines and key indicator to determine the quality service of bus service in selected area. 5 specific areas would be focused in these studies such as on time performance, service frequency, passenger load, service hours and transit auto 
travel time. The analysis gave a quality of service for every three routes in five different areas of the west side of the Klang Valley for the load factor.

In order to determine the stakeholder perception on quality service of bus service in Klang Valley, there were 255 survey have been distributed mainly at every main bus station for each place due to highest number of users such as in Puchong (Tesco Puchong), Subang Jaya (Terminal Metrobus, Subang Jaya), Petaling Jaya (Bus stop Kelana Jaya), Shah Alam (Terminal Seksyen 17, Shah Alam) and Klang (Klang Sentral). These areas have been selected in these studies due strategic location and have high traffic user in this area. The value of the data were determined accordingly such as " $A$ "= Very Good, " $B$ "= Good, " $C$ " =Medium, " $D$ " = Bad and "E"=Very bad represent 5 Marks, 4 Marks, 3 Marks, 2 Marks, and 1 Marks respectively. Selected equation has been used in order to determine Level of Service (LOS) of attribute based on bus performance based on placed. Equation 1 shows the equation that has been used to determine the Quality of Service (QOS). Table 7 shows the Grade of Quality of service for each attribute.

$$
Q O S=\frac{[(A \times N A)+(B \times N B)+(C \times N C)+(D \times N D)+(E \times N E)+(F \times N F)]}{\text { Total of } N} \quad \text { Eq.1 (TCQM, 2013) }
$$

\section{Result}

The data were collected for each selected route for each location. All data were summarized in this section. The three routes of each location from Klang (Route KLG1, KLG2 and 704), Shah Alam (Route T757, T758 and SA01), Subang Jaya (Route T776, T777 and T778), Petaling Jaya (Route PJ02, PJ03 and PJ04), and Puchong (Route T600, T604 and T605) are presented as Routes A, B, and C. The analysis of load factor are presented in Figure 2.

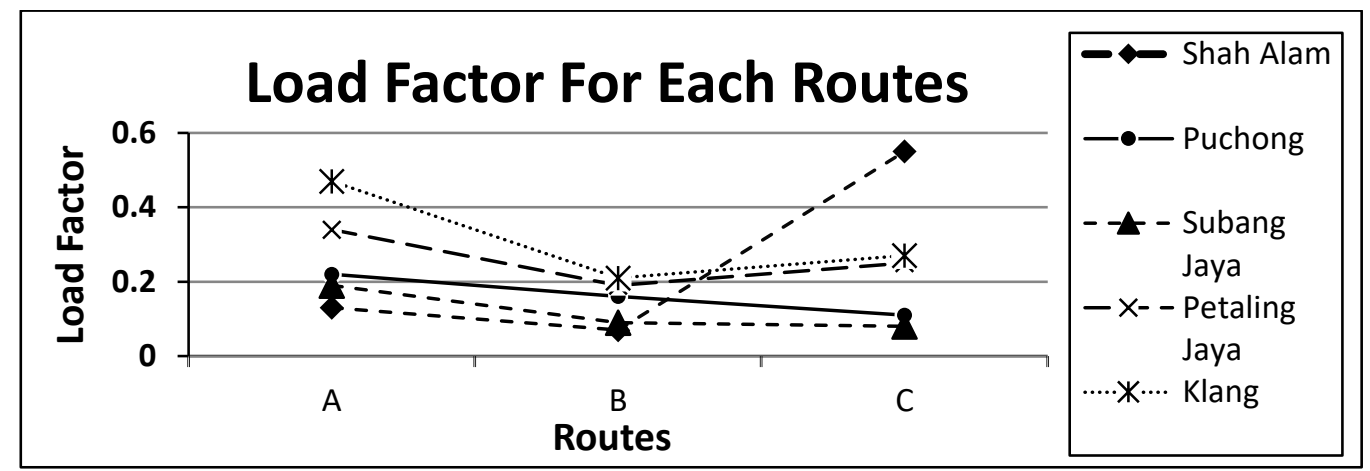

Figure 2: The Load Factor for each route.

From the graph in Figure 2, it can be seen that the lowest passenger load factor at Puchong was for route T605 (C) compared to routes T600 (A) and T604 (B). The reason could possibly be because the places covered by route T605 (C) were not interesting as it mostly covered residential areas and the route was also quite short compared to the other two routes. On the other hand, route PJ02 (A) had the highest passenger load factor among the three routes, and the route mostly covered office areas where the public went to deal with business or personal matters. Thus, route PJ02 (A) had a high passenger load factor compared to routes $\mathrm{PJO3}$ (B) and $\mathrm{PJO4}$ (C).

As routes for those five areas did not have fixed service frequencies, and the number of intervals were determined according to minutes per interval as shown in Figure 3 . The average interval for service frequency at Puchong and Subang Jaya, whose three routes were served by RapidKL, fell into QOS D. The average departure interval for Petaling Jaya also fell 
into QOS D, but it is a free bus service initiated by Majlis Bandaraya Petaling Jaya (MBPJ) and served by PJ City Bus. Therefore, the overall QOS, as in average for the five areas in West Klang Valley, was QOS D.

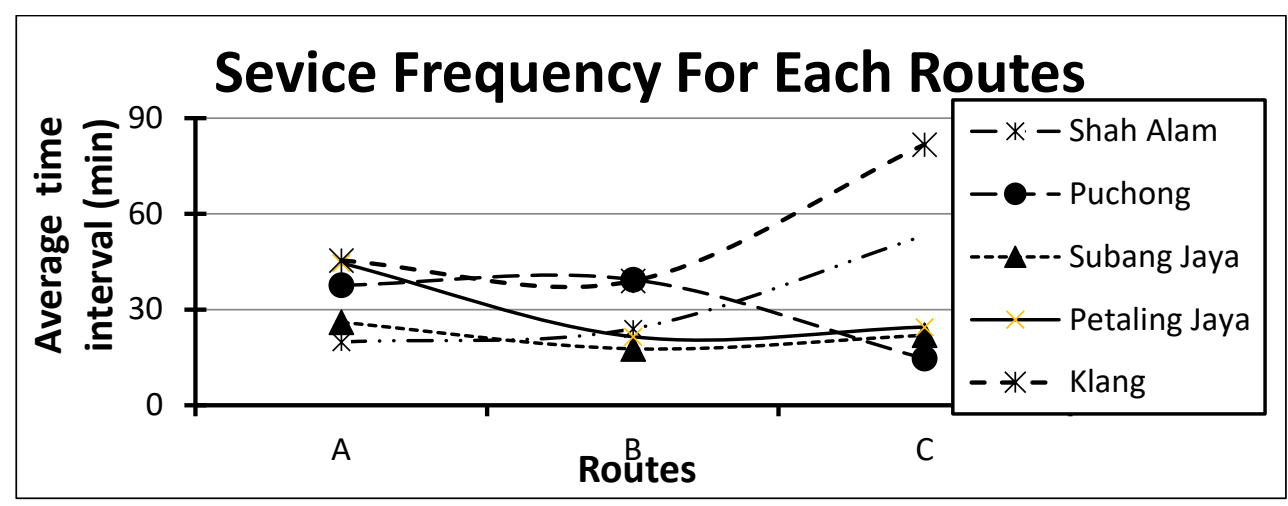

Figure 3: The service frequency for each routes.

The data for service hours were collected for each selected route at each location. Based on the data provided by RapidKL website for Shah Alam, Puchong, Subang Jaya, Petaling Jaya and Klang, the location consisted of $14,7,4,16$ and 12 routes, respectively. The results for bus service hours are summarized in Figure 4. It can be seen that the QOS obtained fell into QOS B for Puchong and Subang Jaya, while QOS C was for Petaling Jaya, Shah Alam and Klang.

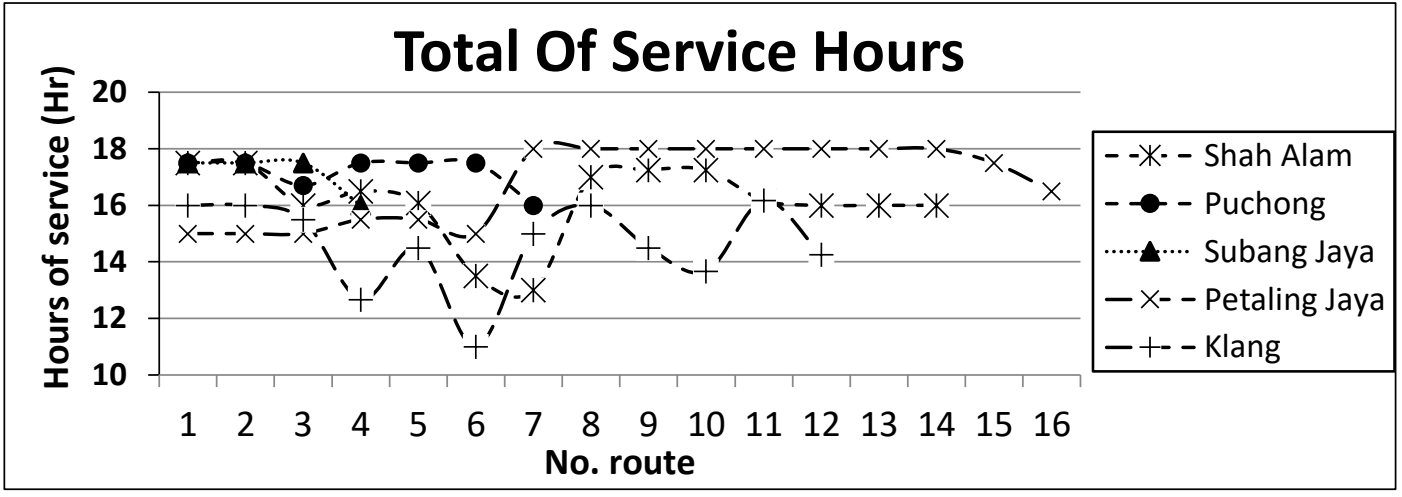

Figure 4: The service hours for each route.

One time performance would be determined by the arrival and departure of buses based on their schedule. Table 1 shows the on time performance percentage and the quality of service based on specific location. Overall, Subang Jaya has the highest on time performance percentage followed by Petaling Jaya, Shah Alam dan Klang. According guidelines, Quality of Service A will give passenger the best time travel with experience any delay on their arrival and departure. The estimation on time performance would be used in these studies starting from the arrival or departure of buses at designated station or location. On time performance would classified between one minute and five minute from original schedule. 
Table 1: On Time Performance Percentage based on Location.

\begin{tabular}{ccc}
\hline Location & $\begin{array}{c}\text { On Time Performance } \\
\text { Percentage (\%) }\end{array}$ & Quality of Service \\
\hline Puchong & 94.78 & $\mathrm{~B}$ \\
Petaling Jaya & 78.49 & $\mathrm{D}$ \\
Subang Jaya & 97.32 & $\mathrm{~A}$ \\
Shah Alam & 82.45 & $\mathrm{C}$ \\
Klang & 71.69 & $\mathrm{D}$ \\
\hline
\end{tabular}

Transit auto travel time would be determine the comparison of travel time between buses and specific auto vehicle. Table 2 shows the transit auto time travel time based different location and time. The results shows that quality of service at Petaling Jaya for both weekdays and weekend is B and Puchong, Subang Jaya and Shah Alam have quality service of C. Only Klang has the quality service of $D$ for transit auto time travel in these studies. Designated lane for buses in peak location such as Puchong and Petaling Jaya affect the transit auto travel time result especially on peak time.

Table 2: Transit Auto Travel Time based on Location.

\begin{tabular}{cccc}
\hline Location & $\begin{array}{c}\text { Average of weekday and } \\
\text { QOS }\end{array}$ & $\begin{array}{c}\text { Average of Weekend and } \\
\text { QOS }\end{array}$ & $\begin{array}{c}\text { Average Ratio and } \\
\text { QOS }\end{array}$ \\
\hline Puchong & $1.21(\mathrm{~B})$ & $1.3(\mathrm{C})$ & 1.26 (C) \\
Petaling & 1.15 (B) & $1.17(\mathrm{~B})$ & 1.16 (B) \\
Jaya & & & \\
Subang Jaya & 1.32 (C) & $1.42(\mathrm{C})$ & 1.37 (C) \\
Shah Alam & 1.34 (C) & $1.27(\mathrm{C})$ & 1.31 (C) \\
Klang & 1.53 (D) & 1.51 (D) & 1.52 (D) \\
\hline
\end{tabular}

In order to evaluate the stakeholder perceptions, there are 500 sheet of survey questionnaire have been distributed at selection location. A 6 questions with 5-focuses Likert scale (from strongly disagree to strongly agree) study questionnaire has been produced. The objective respondents are the general population who were utilizing open transport transportation around West Klang valley, ideally Petaling Jaya, Subang Jaya, Klang, Shah Alam and Puchong. Since the research examine intends to decide the transport execution in West Klang Valley effectively, just respondent who live in the zone are engaged with this survey. Out of the 500 respondents responded, there are 126 users from 10-20 years old age group (about 25.2\%), 230 users from 21-30 years old age group (about 46.0\%), 111 users from 3140 years old age group (about 22.2\%), 12 users from $41-50$ years old age group (about $2.4 \%$ ), and 21 users from more than 50 years old age group (about $4.2 \%$ ). The overall respondent have been identified and analyzed based on the each specific measurement items. Table 3 shows the stakeholder perceptions for 5 different cities in West Klang Valley based on all specific variables. The overall stakeholder perception on quality service of public bus service in West Klang Valley is quality service of B. 
Table 3: Stakeholder Perceptions for Different Locations.

\begin{tabular}{ccccccc}
\hline Locations & $\begin{array}{c}\text { On Time } \\
\text { Performance }\end{array}$ & $\begin{array}{c}\text { Transit } \\
\text { Auto } \\
\text { Travel } \\
\text { Time }\end{array}$ & $\begin{array}{c}\text { Service } \\
\text { Frequency }\end{array}$ & $\begin{array}{c}\text { Service } \\
\text { Hours }\end{array}$ & $\begin{array}{c}\text { Passenger } \\
\text { Load } \\
\text { Factor }\end{array}$ & Overall \\
\hline $\begin{array}{c}\text { Klang } \\
\text { Shah Alam }\end{array}$ & B & C & B & B & C & B \\
Subang & B & C & B & B & B & B \\
Jaya & B & B & B & B & B \\
$\begin{array}{c}\text { Petaling } \\
\text { Jaya }\end{array}$ & B & C & B & B & C & B \\
Puchong & C & C & C & B & C & C \\
\hline Overall & B & C & B & B & C & B \\
\hline
\end{tabular}

Table 4 shows Comparison of Service Quality and Stakeholder's View based on variables. The results shows that, variable of service frequency that has been evaluated by quality of service is D but from stakeholder's view is B. Next, variable of hours of service that has been evaluated by quality of service is C but from stakeholder's view is B. Then, variable of On-time Performance that has been evaluated by quality of service is $C$ but from stakeholder's view is B. Variable of Passenger Load that has been evaluated by quality of service is A but from stakeholder's view is B. Variable of Transit Auto Travel that has been evaluated by quality of service and stakeholder's view are the same which is C. Passenger and user rated the bus services in as their feedback is better than quality of service according transportation guidelines.

Table 4: Comparison of Service Quality and Stakeholder's View based on variables.

\begin{tabular}{ccc}
\hline Variables & Quality of Service & Stakeholders' View \\
\hline Service Frequency & D & B \\
Hours of Service & C & B \\
On-time Performance & C & B \\
Passenger Load & A & B \\
Transit Auto Travel Time & C & C \\
\hline
\end{tabular}

Table 5 shows the comparison of service quality and stakeholder's view based on location. The results shows that Puchong and Petaling Jaya they have the same level of comparison of quality of service and stakeholder' view which is C. While for Subang Jaya, quality of service that been evaluated is C but from stakeholder's view classified as QOS B. For Shah Alam, quality of service that been evaluated is C but from stakeholders' view is $B$. As in Klang, quality of service of bus services that been evaluated as D but stakeholder's view has classified as $\mathrm{C}$. There is several inconsistent result between the quality of service data and stakeholder's view as the quality of service data have been calculated form transportation engineering guidelines meanwhile stakeholder' view have been taken form user or passenger quantitively. Location could be one of the main factors to determine the quality service of buses. In urban area, the bus operator would provide good service as in these area the bus should cater more passenger compare other area. 
Table 5: Comparison of Service Quality and Stakeholder's View based on location.

\begin{tabular}{ccc}
\hline Location & Quality of Service & Stakeholders' View \\
\hline Puchong & C & C \\
Petaling Jaya & C & C \\
Subang Jaya & C & B \\
Shah Alam & C & B \\
Klang & D & C \\
\hline
\end{tabular}

\section{Conclusion}

These studies is to determine the comparison of service quality and stakeholder perception on bus services in West Klang Valley. The data have been collected from five different main cities in West Klang Valley such as Petaling Jaya, Puchong, Subang Jaya, Shah Alam and Klang at selected location. The quality of service have determine based on different area based on public transport guidelines meanwhile stakeholder view were purely take from passenger user based on qualitative measurement to determine quality of service. Petaling Jaya is consider the most central cities in Klang Valley compared with other cities in these studies. The result shows that Petaling Jaya has been classified as $C$ for both quality service and stakeholder perceptions. Klang is consider the outer area in Klang Valley compared with other cities in these studies and it shows that Klang has be classified as D for quality of service and C for stakeholder's view. Based the result, it shows that West Klang Valley has a good bus services and yet there are several issues could be addressed in future such as the certain driver performance could affect the quality service of bus and there are new development area should be reach by bus services. The improvement should be made by bus operator frequently in order to ensure the service quality of bus service could cater a high demand form passenger and user. These studies is repeated in finding new issues these area and also tried to resolve public interest in urban area.

\section{Corresponding Author}

Dr. Shuhairy Norhisham

Senior Lecturer at Universiti Tenaga Nasional, Malaysia College of Engineering Jalan Ikram Uniten, 43000, Kajang, Selangor, Malaysia.

Email: shuhairy@uniten.edu.my

\section{References}

Adebola, O., Samuel, O., Feyisola, A., \& Eno, O. (2014). An Assessment of Public Transport Security and Safety : An Examination of Lagos Bus Rapid Transit (BRT ), Nigeria. Journal Civil and Environment Research, 6(4), 105-117.

Ahmad, F. S., Ihtiyar, A., \& Omar, R. (2014). A Comparative Study on Service Quality in the Grocery Retailing: Evidence from Malaysia and Turkey. 2nd World Conference on Business, Economic And Management - WCBEM 2013, 109, 763-767.

Amiril, A. N. (2014). Transportation Infrastructure Project Sustainability Factors and Performance. Procedia - Social and Behavioral Sciences, 153, 90-98.

Attrad M. (2013). Effects on Service Quality Following Regulatory Reforms in Public Transport in Malta. Transportation Research Board 92nd Annual Meeting, 1-18.

Azadi, M., Shabani, A., Khodakarami, M., \& Farzipoor, S. R. (2015). Planning in feasible region by two-stage target-setting DEA methods: An application in green supply chain 
management of public transportation service providers, Transportation Research Part E: Logistics and Transportation Review, 74, 22-36.

Aziz, A., \& Mohamad, J. (2013). Urban Public Transport in Penang: Some Policy Considerations. Eastern Asia Society for Transportation Studies Conference, 9, 1-19.

Bekhet, H. A., \& Ivy, Y. L. L. (2014). Highlighting energy policies and strategies for the residential sector in Malaysia. International Journal Energy Economic Policy, 4(3), 448456.

Calvo, F., Eboli, L., Forciniti, C., \& Mazzurall, G. (2018). Factors influencing trip generation on metro system in Madrid, Spain, Transportation Research Part D Transport and Environment, 67, 156-172.

Chuen, C. O., Karim, R. M., and Yusoff, S. (2014). Mode Choice between Private and Public Transport in Klang Valley, Malaysia. The Scintific World Journal, 2014, 14.

Eboli, L., Forciniti, C., \& Mazzulla, G. (2018). Spatial variations of the perceived transit service quality at rail stations. Transportation Research Part A Policy and Practice. 114, 67-83.

Eboli, L., \& Mazzulla, G. (2008). A Stated Preference Experiment for Measuring Service Quality in Public Transport. Journal Transportation Planning and Technology, 31(5), 510-521.

Eboli, L., \& Mazzulla, G. (2012). Performance indicators for an objective measure of public transport service quality. Journal of Public Transportation, (51), 1-21.

Ensor, J. D. (2004). Malaysia Transport Pricing Strategies, Measures, And Policies Inception Report. Malaysia Transport Research Group Massachusetts Institute of Technology.

Fonseca, F., Pinto, S., \& Brito, C. (2010). Service quality and customer satisfaction in public transports. International Journal for Research Quality, 4(2), 125-130.

Haron, S., Noor, S. M., Sadullah, A. F. M., \& Vien, L. L. (2010). The Headway Patterns and Potential Parameters of Bus Transportation In Penang. Proceedings of the Malaysian University Transportation Research Forum Conference 2010, 279-290

Ibrahim, N. I., Adji, B. M., \& Karim, M. R. (2013). Public Transport Passengers' Perception and Demand satisfaction: A Case Study at Petaling Jaya Municipal District, Malaysia, Proceedings of the Eastern Asia Society for Transportation Studies, 9, 1-13.

Juan, D. O., Rocia, D. O., Eboli, L., \& Mazzulla, G. (2014). Heterogeneity in Perceptions of Service Quality among Groups of Railway Passengers. International Journal of Sustainable Technology, 9(8), 612-626.

Lin, J. J., \& Wong, I. H. (2014). Optimization of a Feeder-Bus Route Design by Using a Multiobjective Programming Approach. Transportation Planning and Technology. 37(5), 430-449.

Margaret, J. D. L. (2018). Spatial Dynamics Of Tour Bus Transport Within Urban Destinations. Tourism Management, 64, 129-141.

Mazzulla, G., \& Eboli, L. (2006). A Service Quality Experimental Measure for Public Transport Gabriella. European Transport, 34, 42-53.

Ona, D. J., Ona, R. D., Eboli, L., \& Mazzulla, G. (2015). Heterogensity in Perceptions of Service Quality Among Groups of Railway Passengers. International Journal of Sustainable Transportation, 9, 612-626.

Rahmat, R. A. A., (2015). Urban Transportation Planning. UKM Press. 82-84.

Saberi, M., Zockaie, A. K., Feng, W., \& El-Geneidy, A. (2013). Definition and Properties of Alternative Bus Service Reliability Measures at the Stop Level, Journal of Public Transportation, 16(1), 97-122.

Shaaban, K., \& Khalil, R. F. (2013). Investigating the Customer Satisfaction of the Bus Service in Qatar, Procedia - Social and Behavioral Sciences, 104(1), 865-874. 
Soh, K. L., Chong, C. Le, Wong, W. P., \& Hiew, Y. H. (2014). Proclivity of University Students to Use Public Bus Transport Service. Comprehensive Research Journal of Education and General Studies, 2(2), 24-34.

TCQSM. (2013). Transit Capacity and Quality of Service Manual, 3rd Edition. Transit Capacity and Quality of Service Manual.

Vien, L. L., Bagheri, Y., \& Sadullah, A. F. B. M. (2010). Analysis of Headways on Passenger Loads for Public Bus Services: Case Study of Penang Island, Malaysia. Scientific European Journal of Scientific Research, 45(3), 476-483.

Yaakub, N., \& Napiah, M. (2011a). Public Transport: Punctuality Index for Bus Operation. World Academy of Science, Engineering and Technology, 60, 857-862.

Yang, X., Zhang, D., An, J., \& Liu, H. (2010). Passengers' perception based public transportation service quality evaluating methodology. The $6^{\text {th }}$ China Transport Forum in 2015, 115160. 